KONSTRUKTIVISME, Vol. 8, No. 1, Januari 2016

p-ISSN: 0089-9008; e-ISSN: 2442-3545

FKIP Universitas Islam Balitar, Blitar

Web: konstruktivisme.unisbablitar.ejournal.web.id

\title{
NILAI STRATEGIS KURIKULUM \\ PENDIDIKAN BAHASA INGGRIS-BERBASIS KKNI FKIP UNIVERSITAS ISLAM BALITAR
}

\author{
Teguh Budiharso \\ Universitas Mulawarman \\ Email: dr_tgh@yahoo.com
}

\begin{abstract}
This study describes English Language Education Curriculum (ELEC) of Balitar Islamic University delineating needs analysis, tracer study and action plan that is devised considerably upon National Qualification Framework. The study used content analysis implementing qualitative approach. Data were collected from curriculum document, strategic plan of UNISBA, workshop, and Focus Group Discussion conducted at UNISBA for two-month visit. The study revealed that (1) ELEC has been organized in adherence to KKNI containing 144 credits, (2) semesterly course distribution is outlined into: 20 credits each in the first and second semester, 22 credits each in the third up to sixth semester, and 16 credits in seventh semester, (3) diploma supplement as subsequent competency is programmed in terms of workshop in academic literacy, TEFL, enterpreheneurship, IT and computer, and academic writing, (4) competency elements are categorized into: personality development (KPK), work skill (KKK), expertise and knowledge $(\mathrm{KKP})$, methods and knowledge degree (KMK), and managerial skills (KKM) imposed by KKNI.
\end{abstract}

Keywords: curriculum evaluation, learning outcomes, competency.

\begin{abstract}
Abstrak
Penelitian ini bertujuan menjabarkan Kurikulum Pendidikan Bahasa Inggris (PBI) Universitas Islam Balitar berdasarkan hasil analisis kebutuhan, study lacak dan rencana kerja merujuk Kerangka Kualifikasi Nasional. Penelitian menggunakan ancangan analisis isi dan pendekatan kualitatif. Data dikumpulkan dari dokumen kurikulum, Renstra UNISBA, workshop dan FGD selama dua bulan. Hasil penelitian ialah: (1) Kurikulum PBI Unisba telah disusun menurut kerangka KKNI dengan beban kredit 144 sks, (2) sebaran MK menurut semester ialah: 20 sks pada semesterv I dan II, 22 sks pada semester III-VI, dan 16 sks pada semester VII, (3) Diploma Supplement pendukung kompetensi dilaksanakan dalam bentuk workshop literasi akademik, computer, TEFL, kewirausahaan, dan penulisan jurnal ilmiah, (4) pengelompokan bidang kajian disusun menurut Deskripsi Umum dan Deskripsi Khusus KKNI, yaitu: KPK), KKK, KKP, KMK, dan KKM.
\end{abstract}

Katakunci: evaluasi kurikulum, capaian belajar, kompetensi 
Kehadiran Perpres No. 8 Tahun 2012 tentang Kerangka Kualifikasi Nasional Indonesia (KKNI) segera disusul dengan beberapa Peraturan Pemerintah yang disesuaikan dengan isi KKNI. Peraturan Pemerintah yang terkait langsung dengan KKNI di antaranya: (1) Permendikbud No. 73 Tahun 2013 tentang Penerapan KKNI bidang Perguruan Tinggi, (2) Permendikbud No. 49 Tahun 2014 tentang Standar Nasional Pendidikan Tinggi, (3) Permendikbud No. 50 Tahun 2014 tentang Sistem Penjaminan Mutu Pendidikan Tinggi, dan (4) Permendikbud No. 87 Tahun 2014 tentang Akreditasi Program Studi dan Perguruan Tinggi. Peraturan tersebut merupakan dasar adanya policy reform dengan sendirinya mengharuskan adanya curriculum reform yang tindak lanjutnya berupa evaluasi kurikulum sebelum pelaksanaan curriculum change. Dalam konteks Indonesia, inti persoalan ialah perubahan dari Kurikulum Berbasis Kompetensi (KBK) menjadi Kurikulum Berbasis KKNI (KBKNI) atau Kurikulum Berbasis Learning Outcomes (KBO). Untuk pedoman pelaksanaan, pemerintah melalui Dirjen Dikti telah menerbitkan buku Panduan Penyusunan Kurikulum Pendidikan Tinggi (K-DIKTI) pada 2014.

Implikasi curriculum reform tersebut disikapi secara bervariasi dengan persamaan persepsi bahwa cepat atau lambat KBKNI harus dilaksanakan. Law enforcement KKNI telah disusun begitu cermat dalam rangkaian peraturan terkait upaya meyehatan pengelolaan perguruan tinggi di antaranya SNPT, Penjaminan Mutu dan akreditasi Prodi dan Peguruan Tinggi. Jika penyesuaian tidak segera dilakukan, Perguruan Tinggi akan mengalami banyak kendala, misalnya dikurangi atau distop bantuan pendidikan, penelitian, beasiswa, atau ditutup portal layanan online perguruan tinggi yang bersangkutan.

Dari segi penyusunan KBKNI sendiri, terdapat fakta yang juga bervariasi. Dari berbagai forum nasional dan asosiasi Perguruan Tinggi diketahui bahwa perubahan KBK menuju KBKNI menimbulkan permasalahan yang kompleks. Untuk kasus Kurikulum Pendidikan Bahasa Inggris (PBI) yang merupakan fokus kajian artikel ini ditemukan fakta empiris berikut ini. 1) Shopping mata kuliah dengan cara mengunduh secara online mata kuliah dari perguruan tinggi dalam dan luar negeri yang dianggap bonafit dilakukan oleh hampir setiap Prodi PBI. 2) Mata kuliah praktik diberikan sebanyak-banyaknya tanpa mempertimbangkan kerangka keilmuan dalam Kompetensi Utama struktur kurikulum. 3) Memfokuskan lebih banyak pada mata kuliah bidang ilmu, misalnya Teaching dan mata kuliah kebahasaan misalnya Linguistics hanya ditawarkan satu jenis yaitu Introduction to Linguistics. 4) Memberi penekanan pada kompetensi pendukung, misalnya Tourism atau Teaching English for Young Learners. 5) Struktur mata kuliah dalam kurikulum berbeda setiap tahun baik dari jumlah beban studi atau nama mata kuliah.

Dirjen Dikti (2012:30-31) menyoroti kelemahan penyusunan kurikulum pendidikan tinggi dari dua aspek. Pertama, shopping mata kuliah dianggap oleh perguruan tinggi sebagai tolok ukur. Mata kuliah yang dianggap selaras dengan tujuan dan visi perguruan tingginya akan ditempelkan bersama mata kuliah lain ke dalam struktur kurikulum. Menurut Dikti (2010:30) mata kuliah dibangun dengan mempertimbangkan 
Pendidikan Bahasa Inggris Berbasis KKNI FKIP Universitas Islam Balitar. Konstruktivisme, 8(1): 1-19.

fasilitas dan sumber daya yang ada di perguruan tinggi tersebut. Jadi, mengunduh dan menggunakan stragtegi yang dikembangkan oleh perguruan tinggi lain tidak selalu tepat. Kedua, melakukan analisis SWOT (strengths, weaknesses, opportunities, treats) dan tracer study (studi lacak menurut kebutuhan pasar). Berdasar hasil dua study tersebut, ditentukan tujuan pendidikan. Tujuan pendidikan kemudian dijabarkan ke dalam mata kuliah dan penjabaran setiap mata kuliah ke dalam bahan ajar dengan fokus penyusunan penguasaan keilmuan dan cara penerapannya (know how/skills). Di sini susunan mata kuliah dalam kurikulum sangat erat hubungannya dengan logika keilmuan dari suatu program studi. Kurikulum jenis ini disebut dengan Kurikulum Berbasis isi (KBI).

Kehadiran KKNI merupakan pedoman penting untuk menjawab keniscayaan yang tidak bisa dihindari akibat perkembangan global dan perubahan sangat pesat di semua aspek kehidupan. Jika kurikulum pendidikan tinggi tidak disesuaikan dengan perubahan tersebut, lulusan tidak akan laku di pasar kerja dan akan ditinggalkan masyarakat. Di belahan dunia lain, penyesuaian dengan dunia kerja dirumuskan ke dalam National Qualification Framework (NQF) dengan kriteria yang sangat ketat menggunakan standar internasional. Saat ini telah ada lebih 100 negara yang meratifikasi NQF secara nasional dan regional sebagai standar kualifikasi kompetensi lulusan pendidikan formal (Allais, 2010:106). Terkait dengan itu, Johnson, dkk (2015:1) mencatat di berbagai perguruan tinggi mewajibkan penguasaan communication skills sebagai tuntutan wajib. Communication skills di sini mencakup dua hal: academic literacy dan English proficiency.

Academic literacy dalam arti luas ialah kompetensi yang harus dikuasai mahasiswa dalam menempuh perkuliahan agar berhasil. Kompetensi ini meliputi: kemampuan membaca, menulis, dan berbicara secara akademik. Selain itu, kompetensi bidang computer, teknologi, statistic, dan penguasaan internet juga menjadi tuntunan wajib (Johnson, 2015:1-2). Ujud dari kompetensi ini, perguruan tinggi menyiapkan perangkat pembelajaran dan unit pengelola kompetensi secara profesional. Bentuk kegiatan yang ditawarkan ke mahasiswa ialah workshop atau pelatihan bersertifikat yang dalam KKNI disebut dengan diploma supplement.

Penguasaan English proficiency dirancang sebagai kompetensi yang tidak bisa ditawar-tawar. Untuk itu, setiap perguruan tinggi di luar negeri mewajibkan calon mahasiswa menguasai bahasa Inggris sempai level tertentu yang diukur di antaranya menggunakan skor TOEFL atau skor IELTS. Perguruan tinggi menawarkan pelatihan bahasa Inggris dalam bentuk English for Academic Purposes (EAP) yang melatih calon mahasiswa sampai mampu berinteraksi dengan baik dalam perkuliahan. Materi yang diajarkan ialah basic knowledge of English yang meliputi grammar, vocabulary, academic vocabulary, listening, speaking, reading dan writing sebagai entry level behavior dalam mengembangkan academic literacy (Solikhah, 2015).

Permasalahan terkait dengan pengembangan KBKNI, diakui bahwa banyak perguruan tinggi belum menguasai dengan baik KBK. Dasar hukum KBK yang telah dirumuskan dalam SK Mendiknas No. 232/U/2000 
dan SK Mendiknas No. 045/U/2002, belum sepenuhnya dipahami sehingga penerapannya di lapangan masih bervariasi (Depdiknas, 2010). Inti permasalahan dalam konteks ini ialah kompetensi yang dirumuskan dalam struktur kurikulum memiliki kemiripan dengan acuan dalam KKNI. Kelompok mata kuliah dalam KBK dirumuskan ke dalam lima elemen kompetensi yaitu: Pengembangan Kepribadian (MKP), Keilmuan dan Keterampilan (MKK), Keahlian Berkarya (MKB), Perilaku Berkarya (MPB), dan Berkehidupan Bermasyarakat (MBB). Kompetensi dalam kurikulum itu dibangun atas tiga kompetensi: kompetensi utama 40\%-80\%, kompetensi pendukung $20 \%-40 \%$, dan kompetensi lainnya 0-30\%. Kompetensi utama ialah kompetensi yang merupakan ciri lulusan. Ujud dalam kurikulum ialah mata kuliah yang membangun keilmuan dan keterampilan di bidang ilmu yang dilaksanakan oleh Program Studi. Kompetensi pendukung ialah kompetensi lulusan yang masih berhubungan dengan program studi yang bersangkutan namun tidak wajib diberikan pada lulusannya. Kompetensi lainnya ialah kompetensi dari program studi lain yang diambil untuk memperkaya lulusannya (Depdiknas, 2010:30).

Elemen kompetensi versi KBK ini ternyata memiliki kemiripan dengan kompetensi dalam KKNI. Pedoman KKNI menyebutkan rujukan pengembangan bidang kajian yang dibentuk ke dalam mata kuliah ialah Deskripsi Umum dan Deskripsi Spesifik yang dituangkan dalam Perpres No. 12 Tahun 2012 sesuai dengan Jenjang Kualifikasinya (misalnya Sarjana masuk dalam Kualifikasi 6). Meskipun terdapat sedikit perbedaan, antara deskripsi umum dan deskripsi spesifik dalam KKNI dan elemen kompetensi dalam KBK menurut SK Mendiknas No. 232/U/2000 dan SK Mendiknas No. 045/U/2002 dapat disimpulkan bahwa penyepadanan bisa dilakukan mengikuti pola elemen kompetensi dalam KBK. Untuk kurikulum PBI, Solikhah (2015) telah membuat penyepadanan dalam Tabel 1 berikut:

Tabel 1. Istilah dalam KBK dan KKNI dan Kisaran Proporsinya

\begin{tabular}{|c|c|c|c|}
\hline $\begin{array}{l}\text { Istilah dalam KBK } \\
\text { (Menggunakan MK) }\end{array}$ & $\begin{array}{l}\text { Istilah dalam KKNI } \\
\text { (Menggunakan istilah Kajian) }\end{array}$ & SKS & $\%$ \\
\hline $\begin{array}{l}\text { MPK (MK Pengembangan } \\
\text { Kepribadian) }\end{array}$ & $\begin{array}{l}\text { KPK (Kajian Pengembangan } \\
\text { Kepribadian) }\end{array}$ & 8 & 5 \\
\hline $\begin{array}{l}\text { MKK (MK Keilmuan dan } \\
\text { Keterampilan) }\end{array}$ & KKK (Kajian Keterampilan Kerja) & 12 & 8 \\
\hline MKB (MK Keahlian Berkarya) & $\begin{array}{l}\text { KKP (Kajian Keilmuan dan } \\
\text { Pengetahuan) }\end{array}$ & 114 & 78 \\
\hline 1. English Language skills & 1. English Language skills & 66 & 45 \\
\hline 2. English Linguistics & 2. English Linguistics & 8 & 6 \\
\hline 3. English Literature & 3. English Literature & 8 & 6 \\
\hline 4. English Language Teaching & 4. English Language Teaching & 14 & 10 \\
\hline 5. Research Components & 5. Research Components & 6 & 4 \\
\hline 6. Elective Courses & 6. Elective Courses & 12 & 8 \\
\hline MPB (MK Perilaku Berkarya) & $\begin{array}{l}\text { KMK (Kajian Metode dan Tingkat } \\
\text { Kemampuan) }\end{array}$ & 8 & 6 \\
\hline \multirow[t]{2}{*}{$\begin{array}{l}\text { MBB (MK Berkehidupan } \\
\text { Bermasyarakat) }\end{array}$} & $\begin{array}{l}\text { KKM (Kajian Kemampuan } \\
\text { Manajerial) }\end{array}$ & 4 & 3 \\
\hline & Total & 146 & 100 \\
\hline
\end{tabular}


Pendidikan Bahasa Inggris Berbasis KKNI FKIP Universitas Islam Balitar. Konstruktivisme, 8(1): 1-19.

Penyepadanan nomenklatur tersebut sesuai dengan Standar Nasional Pendidikan Tinggi yang dituangkan Permendikbud No. 49 Tahun 2014 tentang Standar Nasional Pendidikan Tinggi Pasal 17 Ayat (1) sampai Ayat (7). Pasal itu memberi petunjuk bahwa di tahun pertama, beban maksimal mahasiswa ialah 20 sks per semester. Tahun kedua dan seterusnya bisa ditambah menjadi 22 sks dengan kekhususan 24 sks bagi mahasiswa yang berprestasi dilihat dari IPK 3.7 ke atas. Ini artinya, sebaran sks jenjang sarjana bisa dibuat menjadi semester I = 20 sks, semester II = 20 sks; dan semester III-VI = masing-masing 22 sks. Semester VII menjadi semester akhir dan untuk total kredit 146 sks mahasiswa tinggal menambah 18 sks termasuk skripsi.

PBI Unisba Blitar, menempatkan visi dan misi perguruan tinggi berupa Perguruan Tinggi berwawasan enterpreneur. Untuk itu, kecenderungan pembelajaran berbasis praktik menjadi tujuan utama. Universitas juga telah menyiapkan berbagai Unit Pelaksana Teknis yang menjembatani keterampilan untuk Diploma Supplement. Pengembangan unit berwawsan enterpreneur ini dalam konteks KBKNI mencakup Pelatihan Penulisan Jurnal IImiah dilengkapi dengan ketersediaan jurnal, unit praktik berbahasa Inggris dalam bentuk Kampung Bahasa Inggris, Unit workshop kewirausahaan, unit workshop kajian keislaman, dan unit workshop Kurikulum dan Pembekajaran Bahasa Inggris (TEFL). Di sini, kurikulum $\mathrm{PBI}$ sudah dilakukan revisi menyesuaikan dengan kerangka KKNI dan mengacu pada pemenuhan standar NQF. Penelitian ini bertujuan mengkaji potensi dan keunggulan Kurikulum PBI Unisba dalam konteks implementasi KKNI di perguruan tinggi.

\section{METODE}

Penelitian ini menggunakan rancangan studi kasus dengan pendekatan kualitatif. Penelitian dilakukan selama dua bulan di FKIP Unisba Blitar. Data dijaring melalui kajian dokumen, wawancara mendalam, angket dan Focus Group Discussion (FGD) dengan melibatkan dosen, pejabat fakultas, pejabat universitas, bagian akademik, dan mahasiswa. Jumlah informan ialah 12 orang terdiri dari para pejaabat di fakultas dan universitas. Data berupa keberadaan kurikulum dan pengembangannya diperoleh dari dokumen kurikulum, dokumen akreditasi Prodi, dan SK Rektor mengenai pelaksanaan kurikulum. Peraturan mengenai kurikulum dan pedoman pengembangan kurikulum KKNI yang terbaru digunakan sebagai rujukan utama dalam merumuskan dan memecahkan masalah. Data mengenai kelemahan dan kelebihan kurikulum serta implementasinya di lapangan diperoleh dari silabus yang dikembangkan oleh dosen, bahan ajar, dan perangkat pembekajaran lainnya. Keterangan lisan hasil dari FGD dan wawancara digunakan untuk membuat needs analysis, SWOT analysis dan tracer study untuk membuat review kurikulum PBI sebelumnya. Hasil review disampaikan melalui workshop selama tiga kali untuk memperoleh balikan mengenai kualitas dan kesesuaian kurikulum hasil revisi. 
KONSTRUKTIVISME, Vol. 8, No. 1, Januari 2016

p-ISSN: 0089-9008; e-ISSN: 2442-3545

FKIP Universitas Islam Balitar, Blitar

Web: konstruktivisme.unisbablitar.ejournal.web.id

\section{HASIL DAN BAHASAN \\ Learning Outcomes}

Learning outcomes dalam kurikilum PBI dirumuskan merujuk pada Deskripsi Umum dan Deskripsi Spesifik KKNI Jenjang 6 untuk program

Sarjana. Learning outcomes terdiri dari learning outcomes Prodi, learning outcome mata kuliah dan learning outcomes lulusan disajikan dalam lampiran. Adapun pengelompokan Bidang Kajian dan proporsi beban studi menurut jenisnya dengan penyepadanan antara KBK dan KKNI disajikan pada Tabel 1.

Tabel 1. Proporsi SKS Menurut Bidang Kajian

\begin{tabular}{lllrr}
\hline \multicolumn{1}{c}{ No } & \multicolumn{1}{c}{ KBK } & \multicolumn{1}{c}{ KKNI } & SKS & $\%$ \\
\hline A & $\begin{array}{l}\text { MPK (Matakuliah } \\
\text { Pengembangan Kepribadian) }\end{array}$ & $\begin{array}{l}\text { KPK (Kajian Pengembangan } \\
\text { Kepribadian) }\end{array}$ & $\mathbf{1 0}$ & $\mathbf{6 . 9 5}$ \\
\hline B & $\begin{array}{l}\text { MKK (Matakuliah Keilmuan dan } \\
\text { Keterampilan) }\end{array}$ & $\begin{array}{l}\text { KKK (Kajian Keterampilan } \\
\text { Kerja) }\end{array}$ & $\mathbf{1 2}$ & $\mathbf{8 . 3 3}$ \\
\hline C & $\begin{array}{l}\text { MKB (Matakuliah Keahlian } \\
\text { Berkarya) }\end{array}$ & $\begin{array}{l}\text { KKP (Kajian Keilmuan dan } \\
\text { Pengetahuan) }\end{array}$ & $\mathbf{1 0 4}$ & $\mathbf{7 2 . 2 2}$ \\
\hline & 1. English Language skills & 1. English Language skills & 46 & 31.94 \\
\hline & 2. English Linguistics & 2. English Linguistics & 14 & 9.72 \\
\hline & 3. English Literature & 3. English Literature & 10 & 6.94 \\
\hline & 4. English Language Teaching & 4. English Language Teaching & 14 & 9.72 \\
\hline & 5. Research Components & 5. Research Components & 8 & 5.55 \\
\hline & 6. Elective Courses & 6. Elective Courses & 12 & 8.33 \\
\hline D & $\begin{array}{l}\text { MPB (Matakuliah Perilaku } \\
\text { Berkarya) }\end{array}$ & $\begin{array}{l}\text { KMK (Kajian Metode dan } \\
\text { Tingkat Kemampuan) }\end{array}$ & $\mathbf{1 0}$ & $\mathbf{6 . 9 5}$ \\
\hline E & $\begin{array}{l}\text { MBB (Matakuliah Berkehidupan } \\
\text { Bermasyarakat) }\end{array}$ & $\begin{array}{l}\text { KKM (Kajian Kemampuan } \\
\text { Manajerial) }\end{array}$ & $\mathbf{8}$ & $\mathbf{5 . 5 5}$ \\
\hline & & & $\mathbf{1 4 4}$ & $\mathbf{1 0 0}$ \\
\hline
\end{tabular}

\section{Deskripsi Kurikulum PBI Unisba}

Karakteristik kurikulum PBI Unisba ditandai dengan penciri berjumlah 144 sks, dijadwalkan dalam 7 semester, beban sks semester I dan II 20 sks, semester III-VI = 22 sks, dan semester terakhir 16 sks. Terdapat kelompok kajian kompetensi untuk kegiatan ekstra kurikuler kewirausahaan dan kajian keislaman sebagai penciri universitas berbasis Islam. Kurikulum juga menyediakan penguatan kompetensi untuk Diploma Supplement yang akan memberi sertifikat kompetensi pendukung ijazah.

\section{Kajian Keislaman}

Kajian keislaman dilaksanakan dalam bentuk kegiatan ekstra kurikuler dalam bentuk Baca Alquran, Praktik Ibadah dan aktifitas di Pondok Pesantren yang dilaksanakan selama dua semester. MK keislaman diberikan sebanyak 6 sks, yaitu (1) Aqidah dan Akhlak, (2) Sejarah Peradaban Islam dan Budaya Jawa, dan (6) Kewirausahaan Islami. MK tersebut dikelompokkan kedalam elemen kompetensi pengembangan kepribadian dan kajian keterampilan kerja. 
Pendidikan Bahasa Inggris Berbasis KKNI FKIP Universitas Islam Balitar. Konstruktivisme, 8(1): 1-19.

\section{Pengisi Entry Level Behavior}

MK penguat keilmuan di sini maksudnya MK yang memberi landasan keterampilan dasar bahasa Inggris. MK ini bertujuan memberi entry level behavior agar mahasiswa memiliki kesamaan kompetensi dan komepetensi minimum yang kurang lebih sama dari awal perkuliahan. MK yang disiapkan untuk ini meliputi: Intensive English Course, Pronunciation Practices, dan General and Academic Vocabulary. MK tersebut diajarkan bersama-sama dengan MK grammar, listening, speaking, reading, dan writing.

\section{MK Kompetensi Utama Penciri Program Studi}

MK pengisi kompetensi utama sebagai penciri Program Studi disusun secara cermat yang ditunjukkan dengan proporsi sks dan persetase menurut kelompoknya. Pertama, bidang keilmuan dikelompokkan ke dalam 6 bidang, yaitu: (1) language skills, (2) linguistics, (3) literature, (4) language teaching, (5) language contents, dan (6) language teaching research. Kedua, proporsi sks setiap bidang keilmuan mencapai rentangan maksimum sehingga ketercukupan kompetensi utama, kompetensi pendukung, dan kompetensi lainnya bisa memadai. Ketiga, ada tiga MK language contents, yang masuk dalam kelompok MK pilihan, tetapi sengaja dimasukkan sebagai MK wajib, yaitu: translation, sociolinguistics, dan discourse analysis atas pertimbangan sumber daya pengajar dan keterbutuhan MK tersebut sebagai komponen kompetensi dalam struktur kurikulum PBI Unisba (Depdikbud, 2010).

MK pilihan dalam kurikulum ini didekati dengan pemahaman bahwa MK tersebut merupakan pengisi keilmuan bahasa. Berhubung jumlah MK tersebut melebihi quota, MK ditawarkan dengan alternatif dan bisa dipilih sesuai jumlah quota sks. Dalam konteks ini dirumuskan MK yang memberi learning outcomes penguat kompetensi KKNI. Tiga MK yang ditawarkan di sini ialah: Academic English Grammar, Writing for Academic Purposes, dan Introduction to Journal Article Writing. MK tersebut bisa diadopsi untuk Prodi lain dan menjadi penguat Diploma Supplement seperti dituntut dalam KKNI. Selanjutnya, diploma supplement dalam bentuk workshop disiapkan berupa: (1) pengisi academic literacy berupa komputer untuk program internet, website, words dan excel, coral \& photoshop, dan analisis data, (2) workshop kewirausahaan sebagai manisfestasi visi UNISBA, dan (3) workshop penguat keilmuan berupa TEFL dan komponennya. UNISBA telah mempersiapkan unit-unit pengembangan untuk mendukung pelaksanaannya baik di bawah struktur Universitas maupun pengembangan mandiri berupa Unit Usaha Mandiri di luar universitas.

\section{Sebaran MK Menurut Elemen Kompetensi}

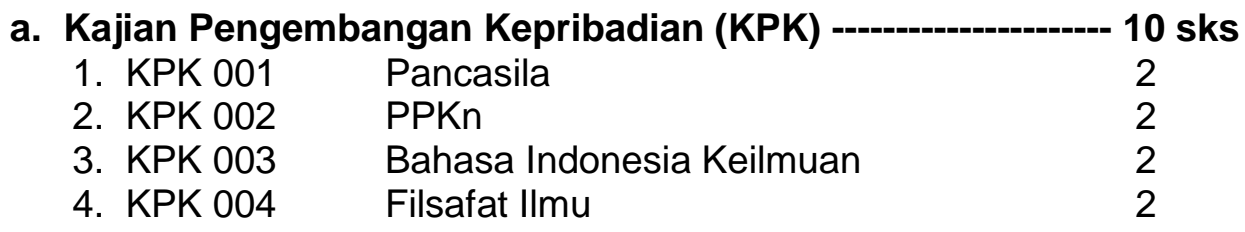


5. KPK 005 Akhlak dan Tasawuf

b. Kajian Keterampilan Kerja (KKK)

2

1. KKK 001

Pengantar IImu Pendidikan

12 sks

2. $\mathrm{KKK} 002$

Perkembangan Peserta Didik

2

3. KKK 003

Belajar \& Pembelajaran

Manajemen Pendidikan

2

4. KKK 004

Sejarah peradaban Islam dan Budaya Jawa 2

5. KKK 005

6. KKK 006

Kewirausahaan Islami

2

c. MK Kompetensi Non-Sks

$16 \mathrm{Js}$

1. KOM 001

Praktik Ibadah

$0 / 4 \mathrm{Js}$

2. KOM 002

Baca Alquran

$0 / 4 \mathrm{Js}$

3. KOM 003

TOEFL Test Taking

$0 / 4 \mathrm{Js}$

4. KOM 004

Computer Literacy

$0 / 4 \mathrm{Js}$

Kajian Keilmuan dan Pengetahuan (KKP)

a. Language Skills (KKPS)

1. KKPS 001

2. KKPS 002

3. KKPS 003

4. KKPS 004

5. KKPS 005

6. KKPS 006

7. KKPS 007

8. KKPS 008

9. KKPS 009

10. KKPS 010

11. KKPS 011 Speaking for Informal Interactions

12. KKPS 012 Speaking for Formal Interactions

13. KKPS 013 Speaking for Academic Purposes

14. KKPS 014 Literal reading

15. KKPS 015 Inferential/Interpretive reading

16. KKPS 016 Critical \& Evaluative reading

17. KKPS 017 Reading for periodical \& literature

18. KKPS 018 Paragraph writing

19. KKPS 019 Composition \& Essay writing

20. KKPS 020 Argumentative Writing

21. KKPS 021 Writing for academic purposes
-104 sks

4

2

2

2

2

2

2

2

2

2

2

2

2

2

2

2

2

2

2

2

$4--46$

b. Linguistics (KKPL)

1. KKPL 001

2. KKPL 002

3. KKPL 003

4. KKPL 004

5. KKPL 005

6. KKPL 006

7. KKPL 007
Introduction to linguistics

English phonology

English morphology

English syntax

Translation

Sociolinguistics

Discourse Analysis
2

2

2

2

2

2

2 ---- 14 
c. Literatures (KKPI)

1. KKPI $001 \quad$ Introduction to literature

2. KKPI 002 Basic analysis of poetry

3. KKPI $003 \quad$ Basic analysis of prose 2

4. KKPI $004 \quad$ Basic analysis of drama 2

5. KKPI 004 Cross cultural understanding 2 --- 10

d. Teaching (KKPT)

1. KKPT 001 English curriculum \& syllabus 2

2. KKPT 002 Coursebook evaluation 2

3. KKPT 003 English materials developments 2

4. KKPT 004 TEFL Approaches 2

5. KKPT 005 TEFL Practices: Micro Teaching 2

6. KKPT 006 Language Learning assessment 2

7. KKPT 007 Language assessment development 2 ---- 14

e. Research Components (KKPR)

1. KKPR 001 Introduction to research methods 2

2. KKPR 002 Research methods in ELT 2

3. KKPR 003 Statistics in Linguistics 2

4. KKPR 004 Data Analysis Quantitative \& Qualitative 2---- 8

f. Optional (KKPO)

1. KKPO 001

English for academic purposes*

2

2. $\mathrm{KKPO} 002$

Semantic-Pragmatic*

2

3. KKPO 003

Psycholinguistics*

2

4. KKPO 004

Teaching English for Young Learners*

2

5. KKPO 005

Second language acquisition*

2

6. KKPO 006

Curriculum \& Program of EYL*

2

7. KKPO 007

Instructional design for SMP/SMA*

2

8. KKPO 008

Trends \& Issues in Linguistics*

9. KKPO 009

Business English*

10. KKPO 010 Journal article writing

11. KKPO 011 Teaching media for EYL*

12. KKPO 012 Applied linguistics*

13. KKPO 013 Semiotics*

Kajian Metode dan Tingkat Kemampuan (KMK)-

10 SKS

1. KMK 001

Internship for teaching observation

2

2. KMK 002

PPL (Internship in Teaching Practices)

3. KMK 003

KKN

4

4

Kajian Kemampuan Manajerial (KKM)

1. KKM 001

Seminar on Thesis Proposal

2. $\mathrm{KKM} 002$

Skripsi 


\section{Diploma Supplement (30 hours)}

1. Computer for academic literacy: Web \& SPSS

2. Workshop on Educational Entrepreneurship

3. Workshop on Design Instructional \& TEFL Practices

4. Workshop on Journal Article Writing

\section{Sebaran Kurikulum Menurut Semester}

\section{SEMESTER I}

\begin{tabular}{|l|l|l|r|}
\hline No & Kode MK & Mata Kuliah & SKS \\
\hline 1 & KPK 001 & Pancasila & $\mathbf{2}$ \\
\hline 2 & KPK 002 & PPKn & $\mathbf{2}$ \\
\hline 3 & KKK 001 & Pengantar Ilmu Pendidikan & $\mathbf{4}$ \\
\hline 4 & KKPS 001 & Intensive English course & $\mathbf{2}$ \\
\hline 5 & KKPS 002 & Pronunciation practices & $\mathbf{2}$ \\
\hline 6 & KKPS 003 & General \& academic vocabulary & $\mathbf{2}$ \\
\hline 7 & KKPS 004 & Basic English grammar & $\mathbf{2}$ \\
\hline 8 & KKPS 008 & Basic listening & $\mathbf{2}$ \\
\hline 9 & KKPS 011 & Speaking for Informal Interactions & $\mathbf{0 / 2}$ \\
\hline 10 & KOM 001 & Praktik Ibadah & $\mathbf{0 / 2}$ \\
\hline 11 & KOM 004 & $\begin{array}{l}\text { Computer Literacy: words, excel, pwr point, } \\
\text { pdf, web }\end{array}$ & $\mathbf{2 0}$ \\
\hline & & & \\
\hline
\end{tabular}

\section{SEMESTER II}

\begin{tabular}{|l|l|l|r|}
\hline Ko & Kode MK & Mata Kuliah & SKS \\
\hline 1 & KPK 004 & Filsafat Ilmu & $\mathbf{2}$ \\
\hline 2 & KPK 005 & Akhlak dan Tasawuf & $\mathbf{2}$ \\
\hline 3 & KKK 002 & Perkembangan Peserta Didik & $\mathbf{2}$ \\
\hline 4 & KKK 003 & Belajar \& Pembelajaran & $\mathbf{2}$ \\
\hline 5 & KKK 004 & Manajemen Pendidikan & $\mathbf{2}$ \\
\hline 6 & KKPS 005 & Intermediate English grammar & $\mathbf{2}$ \\
\hline 7 & KKPS 009 & Intermediate listening & $\mathbf{2}$ \\
\hline 8 & KKPS 011 & Speaking for Formal Interactions & $\mathbf{2}$ \\
\hline 9 & KKPS 014 & Literal reading & $\mathbf{2}$ \\
\hline 10 & KKPS 019 & Paragraph writing & $\mathbf{0 / 2}$ \\
\hline 11 & KOM 002 & Baca Alquran & $\mathbf{0 / 2}$ \\
\hline 12 & KOM 004 & Computer Literacy: Web \& SPSS & $\mathbf{2 0}$ \\
\hline & & & \\
\hline
\end{tabular}


Budiharso, Teguh. 2016. Nilai Strategis Kurikulum

Pendidikan Bahasa Inggris Berbasis KKNI FKIP Universitas Islam Balitar.

Konstruktivisme, 8(1): 1-19.

SEMESTER III

\begin{tabular}{|l|l|l|r|}
\hline No & Kode MK & Mata Kuliah & SKS \\
\hline 1 & KPK 003 & Bahasa Indonesia Keilmuan & $\mathbf{2}$ \\
\hline 2 & KPK 004 & Sejarah Peradaban Islam \& Budaya Jawa & $\mathbf{2}$ \\
\hline 3 & KKPS 006 & Advanced English grammar & $\mathbf{2}$ \\
\hline 4 & KKPS 010 & Advanced listening & $\mathbf{2}$ \\
\hline 5 & KKPS 013 & Speaking for academic purposes \\
\hline 6 & KKPS 015 & Inferential/Interpretive reading & $\mathbf{2}$ \\
\hline 7 & KKPS 020 & Composition \& Essay writing & $\mathbf{2}$ \\
\hline 8 & KKPL 001 & Introduction to linguistics & $\mathbf{2}$ \\
\hline 9 & KKPI 001 & Introduction to literature & $\mathbf{2}$ \\
\hline 10 & KKPI 002 & Basic analysis of poetry & $\mathbf{2}$ \\
\hline 11 & KKPI 004 & Cross cultural understanding & $\mathbf{2}$ \\
\hline & & & $\mathbf{2 2}$ \\
\hline
\end{tabular}

\section{SEMESTER IV}

\begin{tabular}{|l|l|l|r|}
\hline No & Kode MK & Mata Kuliah & SKS \\
\hline 1 & KKPS 007 & Academic English grammar & $\mathbf{2}$ \\
\hline 2 & KKPS 016 & Critical \& Evaluative reading & $\mathbf{2}$ \\
\hline 3 & KKPS 021 & Argumentative Writing & $\mathbf{2}$ \\
\hline 4 & KKPL 002 & English phonology & $\mathbf{2}$ \\
\hline 5 & KKPL 003 & English morphology & $\mathbf{2}$ \\
\hline 6 & KKPI 003 & Basic analysis of prose & $\mathbf{2}$ \\
\hline 7 & KKKI 001 & Basic analysis of drama & $\mathbf{2}$ \\
\hline 8 & KKPT 001 & English curriculum \& syllabus & $\mathbf{2}$ \\
\hline 9 & KKPT 004 & TEFL Approaches & $\mathbf{2}$ \\
\hline 10 & KKPT 006 & Language Learning assessment & $\mathbf{2}$ \\
\hline 11 & KKPR 001 & Introduction to research methods & $\mathbf{0 / 3 0}$ js \\
\hline 12 & DIPLOMA & Workshop on Web \& SPSS & $\mathbf{2 2}$ \\
\hline & & &
\end{tabular}

SEMESTER $V$

\begin{tabular}{|l|l|l|r|}
\hline No & Kode MK & Mata Kuliah & SKS \\
\hline 1 & KKPS 017 & Reading for periodical \& literature & $\mathbf{2}$ \\
\hline 2 & KKPS 021 & Writing for academic purposes & $\mathbf{4}$ \\
\hline 3 & KKPL 005 & Translation & $\mathbf{2}$ \\
\hline 4 & KKPL 006 & Sociolinguistics & $\mathbf{2}$ \\
\hline 5 & KKPT 002 & Coursebook Evaluation & $\mathbf{2}$ \\
\hline 6 & KKPT 005 & TEFL Practices: Micro Teaching & $\mathbf{2}$ \\
\hline 7 & KKPT 007 & Language assessment development & $\mathbf{2}$ \\
\hline 8 & KKPR 002 & Research Methods in ELT & $\mathbf{2}$ \\
\hline 9 & KKPR 003 & Statistics in Linguistics & $\mathbf{2 0 / 2 2}$ \\
\hline 10 & KKPO 002 & Semantic-Pragmatics & ${ }^{\star}$ \\
\hline 11 & KKPO 003 & Psycholinguistics & $\mathbf{2}$ \\
\hline 12 & KKPO 004 & Teaching English for young learners & ( \\
\hline 13 & KOM 003 & TOEFL Test Taking & $\mathbf{2}$ \\
\hline & DIPLOMA & Workshop on Entrepreneurship & $\mathbf{0}$ \\
\hline
\end{tabular}


FKIP Universitas Islam Balitar, Blitar

Web: konstruktivisme.unisbablitar.ejournal.web.id

SEMESTER VI

\begin{tabular}{|l|l|l|r|}
\hline No & Kode MK & Mata Kuliah & SKS \\
\hline 1 & KKPL 002 & English syntax & $\mathbf{2}$ \\
\hline 2 & KKPL 007 & Discourse analysis & $\mathbf{2}$ \\
\hline 3 & KKPT 002 & English Material development & $\mathbf{2}$ \\
\hline 4 & KKPT 003 & Data Analysis: Quantitative \& Qualitative & $\mathbf{2}$ \\
\hline 5 & KKPT 007 & Internship for teaching observation & $\mathbf{2}$ \\
\hline 6 & KKPL 005 & Seminar on thesis proposal & $\mathbf{2 2}$ \\
\hline 7 & KKPO 001 & English for academic purposes & $\mathbf{2}$ \\
\hline 8 & KKPO 005 & Second language acquisition & $\mathbf{2}$ \\
\hline 9 & KKPO 006 & Curriculum \& Program of TEYL & $\mathbf{2}$ \\
\hline 10 & KKPO 007 & Instructional design for SMP/SMA & $\mathbf{2}$ \\
\hline 11 & KKPO 008 & Trends \& Issues in Linguistics & $\mathbf{2}$ \\
\hline 12 & KKPO 009 & Business English* & $\mathbf{2}$ \\
\hline 13 & KKPO 010 & Journal article writing & $\mathbf{2}$ \\
\hline 14 & KKPO 011 & Teaching media in EYL & $\mathbf{2}$ \\
\hline 15 & KKPO 012 & Applied linguistics & $\mathbf{2}$ \\
\hline 16 & KKPO 013 & Semiotics & $\mathbf{2}$ \\
\hline & & ${ }^{*}$ diambil 10 sks $=5$ MK $^{*}$ & $\mathbf{2 2}$ \\
\hline
\end{tabular}

SEMESTER VII

\begin{tabular}{|l|l|l|r|}
\hline No & Kode MK & Mata Kuliah & \multicolumn{1}{|l|}{ SKS } \\
\hline 1 & KKKI 006 & Kewirausahaan Islami & $\mathbf{2}$ \\
\hline 2 & KMK 002 & PPL & $\mathbf{4}$ \\
\hline 3 & KMK 003 & KKN & $\mathbf{4}$ \\
\hline 4 & KKM 001 & Skripsi & $\mathbf{6}$ \\
\hline & & ${ }^{*}$ Yang skripsinya sudah siap boleh ujian & $\mathbf{1 6}$ \\
\hline & DIPLOMA & Workshop on Journal Article Writing & $\mathbf{0 / 3 0}$ \\
& & & js \\
\hline & DIPLOMA & Workshop on Design Instructional on TEFL & $\mathbf{0 / 3 0}$ \\
& & & js \\
\hline
\end{tabular}

\section{SEMESTER VIII}

\begin{tabular}{|l|l|l|r|}
\hline No & Kode MK & Mata Kuliah & SKS \\
\hline 1 & KKM 001 $^{*} \mathbf{6}$ \\
\hline 2 & DIPLOMA $^{*}$ & Skripsi & Workshop on Journal Article Writing \\
$\mathbf{0}$ & $\begin{array}{r}\mathbf{3 0} \\
\text { js }\end{array}$ \\
\hline 3 & DIPLOMA $^{*}$ & $\begin{array}{l}\text { Workshop on Design Instructional \& TEFL } \\
\text { Practices }\end{array}$ & $\begin{array}{r}\mathbf{0 / 3 0} \\
\text { js }\end{array}$ \\
\hline $\begin{array}{l}\text { * Untuk yang belum lulus skripsi atau yang belum menyelesaikan Diploma } \\
\text { Supplement }\end{array}$ \\
\hline
\end{tabular}




\section{RINGKASAN BEBAN STUDI}

\begin{tabular}{|c|c|c|c|c|c|c|c|c|c|}
\hline No & \multicolumn{9}{|c|}{ A. BEBAN SKS MENURUT SEMESTER } \\
\hline 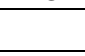 & I & II & III & IV & $\mathbf{V}$ & VI & VII & VIII & Total \\
\hline \multirow[t]{2}{*}{1} & 20 & 20 & 22 & 22 & 22 & 22 & 16 & ${ }^{*} 0 / 6$ & 144 sks \\
\hline & \multicolumn{9}{|c|}{ B. BEBAN STUDI PENGUATAN KOMPETENSI NON SKS } \\
\hline 1 & Cor & puter & Litera & $y: w$ & , ex & pow & oint, & , SPS & $0 / 4 \mathrm{Js}$ \\
\hline \multirow[t]{2}{*}{2} & Pra & tik lb & dah c & $\mathrm{B}$ & Alqu & & & & $0 / 4 \mathrm{Js}$ \\
\hline & \multicolumn{9}{|c|}{ C. DIPLOMA SUPPLEMENT MENURUT KKNI } \\
\hline 1 & \multicolumn{8}{|c|}{ Workshop on Programming of Website \& SPSS } & Sertifika \\
\hline 2 & \multirow{2}{*}{\multicolumn{8}{|c|}{$\begin{array}{l}\text { Workshop on Educational Entrepreneurship } \\
\text { Workshop on Journal Article Writing }\end{array}$}} & Sertifika \\
\hline 3 & \multirow{2}{*}{\multicolumn{8}{|c|}{ Workshop on Instructional Design \& TEFL Practices }} & Sertifika \\
\hline 4 & & & & & & & & & Sertifika \\
\hline
\end{tabular}

\section{SIMPULAN}

Kurikulum PBI Unisba telah dikembangkan mengikuti Pedoman Kurikulum Berbasis KKNI. Kurikulum dirancang mengikuti Pedoman Penerapan Kurikulum KKNI. Keunggulan kurikulum mencakup: (1) beban studi 144 sks ditempuh 7-8 semester, (2) sebaran MK semester I-II masingmasing 20 sks, semester III-VI masing-masing 22 sks, dan semester VII = 16 sks, (3) kurikulum telah memasukkan learning outcomes: kajian keislaman, kajian kompetensi akademik, teknologi, dan kewirausahaan, (4) kompetensi utama penciri bidang studi terstruktur dengan cermat dan menunjukkan antisipasi keilmuan di masa datang, (5) MK penguat kompetensi berupa Diploma Supplement dalam bentuk workshop dan MK penguat akademik, seperti komputer, web, penulisan karya ilmiah, TEFL practices, telah dirancang dengan baik, dan (6) kewirausahaan sebagai visi universitas telah dijabarkan dalam struktur kompetensi utama, kompetensi pendukung, dan kompetensi lainnya. Learning outcomes telah dikembangkan berdasarkan Deskripsi Umum KKNI dan Deskripsi Spesifik KKNI dalam struktur kelompok kajian: (1) KPK (Kajian Pengembangan Kepribadian), (2) KKK (Kajian Keterampilan Kerja), (3) KKP (Kajian Keilmuan dan Pengetahuan), (4) KMK (Kajian Metode dan Tingkat Kemampuan), dan (5) KKM (Kajian Kemampuan Manajerial).

\section{DAFTAR RUJUKAN}

APTISI. 2005. Himpunan Peraturan Perundang-Undangan tentang Pendidikan Tinggi Tahun 1999-2004. Jakarta: APTISI.

Depdiknas. 2010. Buku Pedoman Kerangka Kualifikasi Nasional Indonesia. Jakarta: Direktorat Jendral Pendidikan Tinggi.

Johnson, Steve, Veith, Sarah, Dewiyati, Silvia. 2015. A Framework to embed communication skills across the curriculum: a design-based research approach. Journal of University Teaching \& Learning Practice, 12(4):1-14. 
Keputusan Menteri Agama No. 353 Tahun 2004 Tentang Pedoman

Penyusunan Kurikulum Pendidikan Tinggi di lingkungan PTAI.

Kepmendiknas No. 045/U/2002 tentang Kurikulum Inti Perguruan Tinggi.

Kepmendiknas. No. 232/U/2000 Tentang Pedoman Penyusunan Kurikulum PT dan Penilaian Hasil Belajar Mahasiswa.

Peraturan Presiden Nomor 8 Tahun 2012. Kerangka Kualifikasi Nasional Indonesia. Jakarta: Sekretariat Negara.

Salim, Khalid. 2012. English Language Curriculum in Oman. International Journal of English Linguistics, 2(5):40-44.

Solikhah, Imroatus. 2015a. KKNI dalam Kurikulum Berbasis Learning Outcomes. Lingua, Jurnal Bahasa Sastra dan Pengajarannya. 12(1):1-22. www.jurnal-lingua.info.

Solikhah, Imroatus. 2015b. Learning Outcomes Berbasis Berbasis KKNI dalam Kurikulum Pendidikan Bahasa Inggris. Surabaya: Penerbit Jenggala Pustaka Utama.

Solikhah, Imroatus. 2015c. Reading and Writing as Academic Literacy in EAP Program of Indonesian Learners. Dinamika IImu, 15(2): 325341.

Solikhah, Imroatus. 2014a. Pengembangan Tes Reading for Academic Purposes untuk Mahasiswa EAP di IAIN Surakarta. Pedagogik, 7(1): 46-61. www.jurnal-pedagogik.info.

Solikhah, Imroatus. 2014b. Bahan Ajar Writing For Academic Purposes Berbasis Self-Motivated Learning. Konstruktivisme, 6(2): 111-125. www.jurnal-konstruktivisme.ino.

Universitas Negeri Malang. 2013. Peraturan Dekan Fakultas Sastra No. 7 Tahun 2014. Tentang Standar Kompetensi Lulusan dan Kurikulum Program Studi pada Jurusan Sastra Inggris, Fakultas Sastra. Malang: Fakultas Sastra.

Universitas Islam Balitar. 2015. Pengembangan Visi dan Misi UNISBA 2015-2030. Blitar: Unisba. 


\section{LAMPIRAN: RUMUSAN LEARNING OUTCOMES PBI UNISBA (Diadopsi dari Solikhah, 2015b).}

\section{Learning Outcomes Pengembangan Kepribadian}

Tabel 1. KPK (Kajian Pengembangan Kepribadian)

\begin{tabular}{|c|c|c|}
\hline \multirow{8}{*}{$\begin{array}{l}\text { No } \\
1\end{array}$} & Learning Outcomes & Mata Kuliah \\
\hline & $\begin{array}{l}\text { DESKRIPSI GENERIK KKNI } \\
\text { Sesuai dengan ideologi negara dan budaya bangsa } \\
\text { Indonesia, maka implementasi sistem pendidikan } \\
\text { nasional dan sistem pelatihan kerja yang dilakukan di } \\
\text { Indonesia pada setiap jenjang kualifikasi pada KKNI } \\
\text { mencakup proses yang membangun karakter dan } \\
\text { kepribadian manusia Indonesia sebagai berikut: }\end{array}$ & \multirow[t]{7}{*}{$\begin{array}{l}\text { 1. Pendidikan Agama } \\
\text { 2. Pendidikan Pancasila } \\
\text { 3. PPKn } \\
\text { 4. Bahasa Indonesia }\end{array}$} \\
\hline & a. Bertaqwa kepada Tuhan Yang Maha Esa & \\
\hline & $\begin{array}{l}\text { b. Memiliki moral, etika dan kepribadian yang baik } \\
\text { dalam menyelesaikan tugasnya }\end{array}$ & \\
\hline & $\begin{array}{l}\text { c. Berperan sebagai warga negara yang bangga } \\
\text { dan cinta tanah air serta mendukung } \\
\text { perdamaian dunia. }\end{array}$ & \\
\hline & $\begin{array}{l}\text { d. Mampu bekerja sama dan memiliki kepekaan } \\
\text { sosial dan kepedulian yang tinggi terhadap } \\
\text { masyarakat dan lingkungannya. }\end{array}$ & \\
\hline & $\begin{array}{l}\text { e. Menghargai keanekaragaman budaya, } \\
\text { pandangan, kepercayaan, dan agama serta } \\
\text { pendapat/temuan original orang lain. }\end{array}$ & \\
\hline & $\begin{array}{l}\text { f. Menjunjung tinggi penegakan hukum serta } \\
\text { memiliki semangat untuk mendahulukan } \\
\text { kepentingan bangsa serta masyarakat luas. }\end{array}$ & \\
\hline
\end{tabular}




\section{Keterampilan Kerja}

Tabel 2. Parameter 1: KKK (Kajian Keterampilan Kerja)

\begin{tabular}{|c|c|c|}
\hline \multicolumn{3}{|c|}{$\begin{array}{l}\text { Deskripsi Spesifik: } \\
\text { Mampu mengaplikasikan bidang keahliannya dan memanfaatkan ilmu pengetahuan, } \\
\text { teknologi, dan/atau seni pada bidangnya dalam penyelesaian masalah serta mampu } \\
\text { beradaptasi terhadap situasi yang dihadapi. }\end{array}$} \\
\hline No & Learning Outcomes Prodi & Learning Outcomes Lulusan \\
\hline \multirow[t]{6}{*}{1} & \multirow[t]{6}{*}{$\begin{array}{l}\text { LO 6.1 } \\
\text { Mampu mengaplikasikan } \\
\text { bidang keahliannya dan } \\
\text { memanfaatkan ilmu } \\
\text { pengetahuan, teknologi, } \\
\text { dan/atau seni pada bidangnya } \\
\text { dalam penyelesaian masalah } \\
\text { serta beradaptasi terhadap } \\
\text { situasi yang dihadapi. }\end{array}$} & $\begin{array}{l}\text { 1.1. Mampu mengajar bahasa Inggris di } \\
\text { tingkat SD, SMP, dan SMA menggunakan } \\
\text { bahasa Inggris sebagai media komunikasi } \\
\text { dengan menggunakan bahan ajar dari buku } \\
\text { teks, media online, maupun buatan sendiri } \\
\text { dan mampu memecahkan permasalahan } \\
\text { pembelajaran yang ditemukan di lapangan } \\
\text { secara mandiri. }\end{array}$ \\
\hline & & $\begin{array}{l}1.2 \text { Mampu membuat, memodifikasi, atau } \\
\text { mengembangkan perangkat pembelajaran } \\
\text { bahasa Inggris yang meliputi: kurikulum, } \\
\text { silabus, bahan ajar, metode mengajar, } \\
\text { penilaian dan evaluasi dan } \\
\text { mengimpelemnasikan } \\
\text { dalam proses belajar dan pembelajaran di } \\
\text { lingkungan kerja maupun di masyarakat } \\
\text { secara mandiri. }\end{array}$ \\
\hline & & $\begin{array}{l}\text { 1.3. Mampu mempublikasikan hasil pemikiran } \\
\text { dan hasil karya mengenai permasalahan } \\
\text { pembelajaran bahasa Inggris menggunakan } \\
\text { bahasa Inggris dan bahasa Indonesia secara } \\
\text { terulis dan lisan di lingkungan sendiri atau } \\
\text { masyarakat melalui seminar, media cetak dan } \\
\text { online. }\end{array}$ \\
\hline & & $\begin{array}{l}\text { 1.4. Mampu beradaptasi secara cepat dalam } \\
\text { lingkungan kerja dan berinisiatif serta kreatif } \\
\text { dalam melaksanakan tugas secara mandiri } \\
\text { atau kelompok. }\end{array}$ \\
\hline & & $\begin{array}{l}\text { 1.5. Mampu mengkomunikasikan hasil karya, } \\
\text { permasalahan pembelajaran bahasa Inggris } \\
\text { di lapangan untuk mengatasi permasalahan } \\
\text { yang terjadi di lapangan secara mandiri. }\end{array}$ \\
\hline & & $\begin{array}{l}\text { 1.6. Bersifat kritis, kreatif dan tanggap dalam } \\
\text { mengidentifikasi masalah pembelajaran } \\
\text { bahasa Inggris di lapangan dan menawarkan } \\
\text { alternatif solusi yang relevan dengan } \\
\text { keilmuan dan konteks permasalahan } \\
\text { lapangan. }\end{array}$ \\
\hline
\end{tabular}




\section{Cakupan Keilmuan dan Pengetahuan}

Tabel 3. Parameter 2: KKP (Kajian Keilmuan dan Pengetahuan)

\begin{tabular}{|c|c|c|}
\hline & $\begin{array}{l}\text { ipsi Spesifik: } \\
\text { Iasai konsep teoritis bidang } \\
\text { bagian khusus dalam bidar } \\
\text { u memformulasikan penyele }\end{array}$ & $\begin{array}{l}\text { getahuan tertentu secara umum dan konsep } \\
\text { engetahuan tersebut secara mendalam serta } \\
\text { an masalah prosedural. }\end{array}$ \\
\hline No & Learning Outcomes Prodi & Learning Outcomes Lulusan \\
\hline 2 & $\begin{array}{l}\text { LO } 6.2 \\
\text { Menguasai konsep teoritis } \\
\text { belajar pembelajaran, design } \\
\text { pembelajaran, ilmu bahasa, } \\
\text { sastra, keterampilan } \\
\text { berbahasa Inggris, } \\
\text { pemecahan masalah } \\
\text { pembelajaran bahasa Inggris }\end{array}$ & $\begin{array}{l}\text { 2.1. Memiliki pengetahuan konsep teoritis } \\
\text { belajar pembelajaran dan design } \\
\text { pembelajaran bidang bahasa Inggris yang } \\
\text { meliputi: kurikulum, bahan ajar, metode } \\
\text { mengajar, penilaian, pengelolaan kelas dan } \\
\text { konsep pendukung yang relevan untuk bahan } \\
\text { pengambilan putusan secara praktis, kreatif } \\
\text { dan inovatif di lapangan. }\end{array}$ \\
\hline & $\begin{array}{l}\text { menguatkan penyelesaian } \\
\text { masalah dan pekerjaan } \\
\text { bidang pembelajaran bahasa } \\
\text { Inggris. }\end{array}$ & $\begin{array}{l}\text { 2.2 Memiliki pengetahuan teoritis mengenai } \\
\text { ilmu bahasa yang meliputi linguistik, sastra } \\
\text { dan bahasa terapan seperti sosiolinguistik, } \\
\text { analisis wacana, pragmatik dan literasi } \\
\text { berbahasa Inggris yang tercakup dalam } \\
\text { keterampilan berbahasa Inggris dan ilmu } \\
\text { pendukung lain yang relevan dengan proses } \\
\text { pembelajaran dan pengembangan perangkat } \\
\text { pembelajaran bahasa Inggris serta } \\
\text { memecahkan masalah di lapangan. }\end{array}$ \\
\hline & & $\begin{array}{l}\text { 2.3. Mampu mengkomunikasikan konsep } \\
\text { teoritis mengenai permasalahan } \\
\text { pembelajaran, perangkat pembelajaran, } \\
\text { kebahasaan, metode pembelajaran dan } \\
\text { alternatif solusinya kepada siswa, guru, dan } \\
\text { masyarakat pengguna secara lisan atau } \\
\text { tertulis. }\end{array}$ \\
\hline & & $\begin{array}{l}\text { 2.4. Memiliki konsep teoritis mengenai } \\
\text { penilaian dan evaluasi pembelajaran Bahasa } \\
\text { Inggris untuk pedoman pengembangan } \\
\text { perangkat penilaian, evaluasi, dan } \\
\text { pemecahan masalah di lapangan. }\end{array}$ \\
\hline
\end{tabular}




\section{Metode dan Tingkat Kemampuan}

Tabel 4. Parameter 3: KMK (Kajian Metode dan Tingkat Kemampuan)

\begin{tabular}{|c|c|c|}
\hline \multicolumn{3}{|c|}{$\begin{array}{l}\text { Deskripsi Spesifik: } \\
\text { Mampu mengambil keputusan yang tepat berdasarkan analisis informasi dan } \\
\text { data, dan mampu memberikan petunjuk dalam memilih berbagai alternatif solusi } \\
\text { secara mandiri dan kelompok. }\end{array}$} \\
\hline No & Learning Outcomes Prodi & Learning Outcomes Lulusan \\
\hline \multirow[t]{5}{*}{2} & \multirow{2}{*}{$\begin{array}{l}\text { LO } 6.2 \\
\text { Mampu mengidentifikasi } \\
\text { permasalahan dari berbagai } \\
\text { sumber dan beragam jenis } \\
\text { data dan bisa bekerja sama } \\
\text { serta berkomunikasi secara } \\
\text { efektif dalam sebuah } \\
\text { kelompok baik sebagai } \\
\text { anggota atau pimpinan } \\
\text { kelompok, untuk } \\
\text { menyelesaikan pekerjaan } \\
\text { bidang pembelajaran bahasa } \\
\text { Inggris dan } \\
\text { mendokumentasikan hasil } \\
\text { pekerjaan dalam bentuk } \\
\text { laporan tertulis. }\end{array}$} & $\begin{array}{l}\text { 3.1. Mampu menerapkan proses } \\
\text { pengambilan data dan informasi secara } \\
\text { ilmiah dan objektif menggunakan berbagai } \\
\text { teknik pengumpulan data untuk bahan } \\
\text { analisis dan pengambilan simpulan secara } \\
\text { objektif dan benar. }\end{array}$ \\
\hline & & $\begin{array}{l}\text { 3.2. Mampu menyesuaikan diri dengan } \\
\text { cepat di lingkungan kerja, mengambil } \\
\text { keputusan secara objektif dan dapat } \\
\text { bekerjasama dalam kerja kelompok } \\
\text { (teamwork). }\end{array}$ \\
\hline & & $\begin{array}{l}\text { 3.3. Mampu menyiapkan laporan tertulis } \\
\text { tentang hasil pekerjaan baik yang menjadi } \\
\text { tanggungjawab sendiri maupun } \\
\text { tanggungjawab kelompok, mengenai } \\
\text { analisis, rancangan, maupun implementasi } \\
\text { suatu program pembelajaran. }\end{array}$ \\
\hline & & $\begin{array}{l}\text { 3.4. Mampu menerapkan teknik-teknik } \\
\text { komunikasi individu dan komunikasi } \\
\text { kelompok secara efektif. }\end{array}$ \\
\hline & & $\begin{array}{l}\text { 3.5. Mampu menerapkan etika pergaulan, } \\
\text { norma agama, norma sosial, dan etika dan } \\
\text { menghargai keragaman pendapat, } \\
\text { kekurangan dan kelebihan setiap anggota } \\
\text { kelompok di lingkungan kerja. }\end{array}$ \\
\hline
\end{tabular}




\section{Kemampuan Manajerial}

Tabel 5. Parameter 4: KKM (Kajian Kemampuan Manajerial)

\section{Deskripsi Spesifik:}

Bertanggung jawab pada pekerjaan sendiri dan dapat diberi tanggung jawab atas capaian hasil kerja organisasi.

\begin{tabular}{|c|c|c|}
\hline \multirow{7}{*}{\begin{tabular}{|l} 
No \\
2
\end{tabular}} & Learning Outcomes Prodi & Learning Outcomes Lulusan \\
\hline & \multirow{6}{*}{$\begin{array}{l}\text { LO } 6.4 \\
\text { Mampu melakukan evaluasi } \\
\text { dan supervisi terhadap } \\
\text { capaian hasil kerja di bidang } \\
\text { pembelajaran bahasa Inggris } \\
\text { yang menjadi } \\
\text { tanggungjawabnya baik } \\
\text { sebagai anggota atau } \\
\text { pimpinan dalam kelompok } \\
\text { kerja. }\end{array}$} & $\begin{array}{l}\text { 4.1. Mampu melakukan evaluasi terhadap } \\
\text { pekerjaan yang menjadi tanggungjawab } \\
\text { sendiri dan sebagai pimpinan kelompok. }\end{array}$ \\
\hline & & $\begin{array}{l}\text { 4.2. Memiliki sikap kritis, kreatif, inovatif dan } \\
\text { disiplin tinggi dalam bekerja secara mandiri } \\
\text { maupun kelompok serta menjunjung tinggi } \\
\text { norma akademik, etika dan keragaman } \\
\text { pendapat, agama, etnis, dan kepribadian } \\
\text { anggota tim. }\end{array}$ \\
\hline & & $\begin{array}{l}\text { 4.3. Mampu melakukan supervisi dan } \\
\text { evaluasi terhadap pekerjaan yang menjadi } \\
\text { tanggungjawab kelompok kerja yang } \\
\text { dipimpinnya. }\end{array}$ \\
\hline & & $\begin{array}{l}\text { 4.4. Mampu menganalisis permasalahan } \\
\text { dengan cepat untuk menemukan solusi } \\
\text { dengan mengedepankan kebersamaan, } \\
\text { tanggungjawab, dan keberagaman anggota } \\
\text { tim. }\end{array}$ \\
\hline & & $\begin{array}{l}\text { 4.5. Mampu menyusun laporan tertulis dan } \\
\text { lisan dan mengkomunikasikan isi laporan } \\
\text { dengan tim dan lingkungan kerja secara } \\
\text { pribadi dan penangqung jawab organisasi. }\end{array}$ \\
\hline & & $\begin{array}{l}\text { 1.6. Mampu menggerakkan dinamika } \\
\text { kelompok dan partisipasi aktif anggota } \\
\text { kelompok sampai tujuan organisasi berhasil } \\
\text { dengan penuh tanggung jawab. }\end{array}$ \\
\hline
\end{tabular}

